\title{
Ikä ja koulutettavuuden dilemmat viisikymppisten ja kuusikymppisten naisten kerronnassa
}

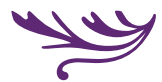

Aikuislukiosta valmistuneet viisikymppiset ja kuusikymppiset naiset ovat vastanneet "uuden aikuisuuden" haasteeseen jatkuvasta oppimisesta ja itsensä kehittämisestä. Heidät asetetaan kuitenkin erilaisiin asemiin suhteessa elinikäiseen oppimiseen: viisikymppisille aikuislukio avaa legitiimin elinikäisen oppijan statuksen, kuusikymppiset asetetaan paitsi työelämän myös elinikäisen oppimisen reunamille ja takapihalle.
\end{abstract}

SUOMEN JA KOKO Euroopan väestörakenteen on ennustettu muuttuvan merkittävästi tulevina vuosikymmeninä. Suuret ikäluokat ovat siirtymässä eläkkeelle ja eläkeläisten määrä kasvaa myös pidentyneestä eliniästä johtuen. Samalla työvoiman määrä pienenee: työmarkkinoilta poistuu enemmän työntekijöitä kuin sinne tulee. Ikääntyvän työvoiman merkitystä työmarkkinoilla on alettu korostaa ja pohdittu keinoja työurien pidentämiseksi ja eläkeiän nostamiseksi. Toisaalta keskustelussa korostuu myös aktiivinen ikääntyminen ja aktiivinen kansalaisuus, joka kytkeytyy elinikäisen oppimisen periaatteisiin (Euroopan yhteisöjen komissio 2000). "[T] avoitteena on luoda Eurooppa, jossa jokainen voi kehittää mahdollisuuksiaan täysimittaisesti, tuntea pystyvänsä osallistumaan ja tuntea kuuluvansa joukkoon” (mt., 5).

Elinikäisen oppimisen mahdollisuus ja myös välttämättömyys jatkuvasti muuttuvassa tietoyhteiskun- nassa ei koske pelkästään lapsia ja nuoria, vaan myös aikuisten on oltava valmiita oppimaan ja kouluttautumaan. Näin voidaan taata riittävä työvoima myös tulevaisuudessa (Euroopan yhteisöjen komissio 2000). Leena Koski ja Erja Moore (2001) ovatkin esittäneet, että ihminen ei ole koskaan valmis, vaan niin sanottu "uusi aikuisuus" edellyttää jatkuvaa oppimista ja itsensä kehittämistä. Ihminen on muutoksen ja joksikin tulemisen tilassa kehdosta hautaan. Elinikäinen oppiminen edellyttää oikeaa asennetta ja halua elämänlaajuiseen oppimiseen kaikissa oppimisympäristöissä. Siihen sisältyy myös tulkinta kaikkia koskevasta koulutettavuudesta.

Artikkeli pohjautuu väitöskirjatutkimukseeni (Siivonen 2010a), jossa tarkastelin kahdenkymmenen aikuislukiosta valmistuneen opiskelijan narratiivisissa elämänhistorioissa tekemiä tulkintoja ja merkityksenantoja itsestään opiskelijoina ja oppijoi- 
na. Tutkimukseen osallistui viisitoista naista ja viisi miestä. Heistä kaksitoista oli alle 40-vuotiaita, neljä 40-60-vuotiaita ja neljä yli 60-vuotiaita. Väitöstutkimuksen ja tämän artikkelin lähtökohtana on koulutettavuuden tulkintoihin sisältyvä ristiriita: yhtäältä elinikäinen oppiminen rohkaisee kaikkia ikään, sukupuoleen ja sosiaaliluokkaan katsomatta oppimaan ja kouluttautumaan, toisaalta koulun käytännöissä opiskelijat jaotellaan ”synnynnäisten” kykyjensä mukaisiin hierarkkisiin kategorioihin ja vain lahjakkaimmat ohjataan akateemisille urille.

Tässä artikkelissa tarkastelen aineiston viisikymppisten ja kuusikymppisten naisten narratiivisia elämänhistorioita (ks. Taulukko 1.) ja heidän tulkintojaan iästä ja koulutettavuudesta suhteessa elinikäiseen oppimiseen ja muuttuvan työelämän haasteisiin. Ikääntyvät viisikymppiset ja ikääntyneet kuusikymppiset asettuvat erilaisiin asemiin suhteessa työelämään (IKOMI, Ikääntyvät työelämässä 1996; Paloniemi 2004). Työelämässä 50-vuotiaan saatetaan katsoa olevan jo liian vanha. Missä määrin tämä koskee myös oppimista ja kouluttautumista? Onko opiskelijalla parasta ennen ikä ${ }^{1}$ ?

Elinikäisen oppimisen periaatteiden toteuttajina aikuislukiot ovat toimineet edelläkävijöinä. 85-vuotisen historiansa aikana ne ovat tarjonneet joustavia ja yksilöllisiä opiskelumahdollisuuksia "aikuisille, joilla ei ole ollut lapsina tai nuorina mahdollisuutta, kiinnostusta tai kypsyyttä hankkia tätä koulutusta” (OPM 2006, 20). Ikä ei ole ollut este aikuislukioopinnoille, sillä opiskelemaan hyväksytään kaikki 18 vuotta täyttäneet ja keskikoulun tai peruskoulun oppimäärän suorittaneet aikuiset (aikuislukioiden toiminnasta ks. IKLO 2007). Aikuislukio-opintojen tavoitteellisuus -lukion päättötodistukseen ja ylioppilastutkintoon johtava yleissivistävä koulutus tai yksittäisissä aineissa suoritetut kurssit - on taannut aikuislukiolle itsestään selvän aseman elinikäisen oppimisen periaatteiden toteuttajana. Eri puolilla Suomea toimivat noin 50 aikuislukiokoulutusta tarjoavaa instituutiota antavat opiskelijoille mahdollisuuden täydentää laaja-alaisesti yleissivistystään sekä parantaa jatko-opiskelumahdollisuuksia, ammatillisia valmiuksia ja työelämässä menestymisen edellytyksiä (Siivonen 2010b).
Näennäisestä tasa-arvosta huolimatta tutkijat ovat osoittaneet, että elinikäinen oppiminen on 1990-luvulta alkaen kiinnittynyt ennen muuta taloudellisiin motiiveihin (ks. esim. Fejes 2005; 2006; Olssen 2006; Siivonen 2010a). Sivistyksen sijaan korostuu koulutuksen työelämälähtöisyys ja yksilöiden työllistettävyys (ks. Boden \& Nevada 2010; Brown, Hesketh, Williams 2003; Filander 2006). Hanna Ojala onkin halunnut korostaa elinikäisen oppimisen ikäsidonnaisuutta ja uudelleen määritellyt elinikäisen oppimisen työelämänikäiseksi oppimiseksi (ks. Ojala 2010, 81-82). Hänen mukaansa elinikäinen oppiminen koskee ainoastaan aktiivisessa työiässä olevia sekä työelämään tulevaisuudessa siirtyviä lapsia ja nuoria (mt.).

Elinikäisen oppimisen periaate kaikille tasa-arvoisista mahdollisuuksista oppia ja kouluttautua tulee väitöskirja-aineistossani esiin näkemyksenä opiskelijoiden eri-ikäisyydestä rikkautena. Eri-ikäiset ja erilaisin elämänkokemuksin varustetut opiskelijat kokivat olevansa ikään kuin "samalla viivalla" aikuislukiossa opiskellessaan. Tästä huolimatta ikä nousee esiin aikuislukiosta valmistuneiden opiskelijoiden kerronnassa erottelevana kategoriana suhteessa opiskelulle ja oppimiselle annettuihin merkityksiin ja elinikäisen oppimisen periaatteisiin. Opiskelu nähdään pikemminkin nuoruuteen kuin aikuisuuteen kuuluvana elämänvaiheena.

Myös sukupuoli ja sosiaaliluokka kietoutuvat ikään ja koulutettavuuden suhteen rakentuviin merkityksiin. Vaikka aineistossa ei ole yhtään ikääntyvää tai ikääntynyttä miestä, myös iäkkäät miehet ovat aineistoni naisten kertomuksissa läsnä peilinä käsityksille itsestä oppijana. Lapsuudenkodistaan naiset kertovat työväenluokkaisena ja vaatimattomana (ks. Taulukko 1.). Olemassa olevat sosiaaliset ja materiaaliset resurssit osaltaan muokkaavat käsityksiä omasta oppimisesta ja mahdollisuuksista kouluttautua. Miten ikä ja siihen kietoutuvat sukupuoli ja sosiaaliluokka rakentavat koulutettavuuden sosiaalisia eroja viisikymppisten ja kuusikymppisten naisten kerronnassa? Miten koulutettavuus rakentuu tarkasteltavana olevien naisten kerronnassa suhteessa elinikäisen oppimisen diskurssiin? 


\section{IKÄ JA KOULUTETTAVUUDEN DILEMMAT}

Koulutettavuus määrittyy artikkelissani tulkinnaksi siitä, kenellä on oikeus koulutukseen ja millaiseen koulutukseen (Häyrynen \& Hautamäki 1973). Koulutettavuuden tulkintoihin sisältyy ristiriita elinikäiseen oppimiseen sisältyvän tasa-arvoisen, kaikkia koskevan koulutettavuuden ja meritokraattisen, koulujen ylläpitämän, yksilön luonnollisiin kykyihin perustuvan koulutettavuuden välillä. Opiskelijat jaetaan koulun ylläpitämin arviointikriteerein kykyjensä mukaisiin hierarkkisiin kategorioihin "hyvät", "keskinkertaiset" ja "huonot" (Räty \& Snellman 1998). Jako teoreettisiin ja käytännön kykyihin ja niihin kytkeytyviin kouluaineisiin sekä loogis-matemaattisiin miesten ja kielellis-sosiaalisiin naisten kykyihin rakentaa koulutettavuuteen liittyviä sosiaalisia eroja suhteessa sosiaaliluokkaan ja sukupuoleen (esim. Räty 2001; Räty, Kasanen \& Kärkkäinen 2006; Walkerdine 1998). Alemmista sosiaalisista luokista tulevia rohkaistaan käytännön ammatteihin ja akateemisista kodeista tulevia akateemiselle uralle; naisia naisten ja miehiä miesten töihin (ks. esim. Käyhkö 2006).

Elinikäiseen oppimiseen sisältyvä "ikä"-käsitys asettuu jännitteiseen suhteeseen myös suhteessa kulttuurisiin ikäjärjestyksiin. Ikään liittyvät normit, kuten lukion suorittaminen nuorena, säätelevät edelleen koulutettavuutta (Siivonen 2010a). Sinikka Aapola (2002) on todennut, että ylioppilastutkinnon suorittaminen ja lakkiaisjuhlat ovat tyypillisiä ikään liittyviä kulttuurisia rituaaleja, jotka symboloivat siirtymää opiskelijasta yhteiskunnan täysivaltaiseksi jäseneksi, aikuiseksi. Valkoinen ylioppilaslakki symboloi vastavalmistuneen kantajansa statusta (mt.). Uuteen ylioppilaaseen liitetään määreet "nuoruus ja tulevaisuus" ja ylioppilaista on puhuttu "tulevaisuuden toivoina" (Vuorio-Lehti 2006, 15). Toisaalta kuitenkin elinikäisen oppimisen ideologiaa leimaava "iättömyys" tulee myös esiin aikuislukiossa, jossa eri-ikäiset ja eri koulutussukupolvia edustavat opiskelevat yhdessä. Tämä on poikkeus suomalaisessa koulujärjestelmässä, jossa ikäluokat ovat perinteisesti opiskelleet yhdessä (Aapola 1999a; 2002).

Ikään ja oppimiseen liittyy edelleen runsaasti myös ennakkoluuloja. Ajatellaan esimerkiksi, että kyky oppia uusia asioita ja taitoja häviäisi iän myötä
(Paloniemi, 2004, 32). Jorma Kuusinen (2003, 173) kuitenkin toteaa, että kyky oppia säilyy pitkälle vanhuuteen ja ikämuutokset johtuvat pikemminkin kykyjen käyttämättömyydestä kuin todellisesta ikämuutoksesta. Ikääntyvien on myös todettu hallitsevan suuria kokonaisuuksia paremmin ja hyötyvän elämänkokemuksestaan oppimisessa (ks. Paloniemi 2004). Vaikeudet käyttää symbolisesti ja kulttuurisesti maskuliiniseksi miellettyä uutta teknologiaa yhdistetään usein myös ikään ja erityisesti naisiin (Korvajärvi 1999; ks. myös Uotinen 2005).

Lukion suorittaminen aikuisuudessa voidaan siis yhtäältä nähdä yksilöllisenä elinikäisen oppimisen postmodernina projektina, joka rikkoo normatiivista sosiaalista elämänkulun järjestystä (ks. Aapola 1999b; Alheit \& Dausien 2002). Toisaalta kuitenkin ikä linkittyy aikaan ja kulttuurisiin ja institutionaalisiin käytäntöihin kuten oppivelvollisuuteen ja eläkkeelle siirtymiseen (Ojala 2010, 57). Aikuislukio-opiskelijalle ei ole yläikärajaa, mutta työntekijän lakisääteiseksi eläkeiäksi on määritelty 68 vuotta. Opiskelun ja oppimisen kaventuminen työikäisyydeksi (mt., 82) vaikuttaa myös aikuislukio-opiskelijan koulutettavuuden määrityksiin.

\section{METODOLOGIA JA AINEISTO}

Tutkimukseen osallistuneiden aikuislukiosta valmistuneiden opiskelijoiden elämänhistoriallinen jatkuvuustyö (Linde 1993) muodostaa kurkistusaukon, joka mahdollistaa koulutettavuuteen liittyvien ristiriitojen tarkastelun. Lukiokoulutus on osa suomalaista koulujärjestelmäkoulutusta, joka normatiivisesti suoritetaan nuorena eikä aikuisuudessa. Lukion suorittaminen aikuisuudessa luo elämänhistoriallista epäjatkuvuutta, jota Charlotte Linden $(1993,152) \mathrm{mu}-$ kaan täytyy arvioida ja selittää. Elämänhistoriallinen kerronta toimii tällöin mahdollisuutena ja resurssina koulutettavuutta koskevien käsitysten uudelleen tulkintaan. Tämä ei kuitenkaan tapahdu sosiaalisessa ja kulttuurisessa tyhjiössä, vaan kertojan sosiaalinen asema sekä historialliseen ja sosiokulttuuriseen kontekstiin kiinnittyvä subjektiivinen elämänkulku (Alheit \& Dausien 2002; Ojala 2005, 2010) määrittävät opiskelulle ja oppimiselle annettuja merkityksiä.

Kertojalla ja kuulijalla on käytössään erilaisia 
kulttuurissa hyväksyttyjä tapoja luoda jatkuvuutta. Minän kertominen pätevänä ja ajassa jatkuvana ja riittävän perustelun antaminen tietylle tapahtumalle (Linde 1993) ovat tärkeimpiä kertojan käytössä olevia kerronnallisia resursseja. Elämänhistoriallisessa kerronnassa kertoja ja päähenkilö ovat erillisiä, mikä mahdollistaa sen, että kertoja voi kommentoida ja arvioida päähenkilön toimintaa ja silti aina itse osoittautua päteväksi (Linde 1993, 123-124). Myös yhteiset kulttuuriset kertomukset, kuten koulutuskertomukset, toimivat kerronnassa jatkuvuuden rakentamisen resursseina (Komulainen 1998, 34-38).

Paitsi elämänhistoriallista jatkuvuutta luen myös elämänhistorioiden sisällä olevia narratiiveja, 'pieniä kertomuksia'. Sovellan analyysissä Michel Bambergin ja Alexander Georgakopouloun (2008) kehittämää positiontimallia. Analyysissä huomio kiinnittyy sosiaalisiin toimintoihin, joita narratiivit performoivat ihmisten elämässä, toisin sanoen, miten ihmiset käyttävät kertomuksia arkipäiväisissä tilanteissa luodakseen ja pitääkseen yllä kuvaa itsestään ja siitä, keitä he ovat. Miten kertomuksen henkilöt asemoituvat suhteessa toisiinsa sekä aikaan ja paikkaan tai miten heidät asemoidaan? Millaiseen positioon kertoja itse asettuu tai asetetaan? Miten kertoja asemoi itsensä suhteessa valtadiskursseihin tai suuriin kertomuksiin kuten koulun ylläpitämään meritokraattiseen diskurssiin ja elinikäisen oppimisen diskurssiin?

Floya Anthias (2005) on todennut, että kertoessamme tarinoita me samanaikaisesti kerromme siitä, miten me paikannamme itsemme suhteessa sosiaalisiin kategorioihin kuten sukupuoleen ja luokkaan tiettynä aikana ja tietyssä paikassa. Ikä, sukupuoli ja sosiaaliluokka määrittyvät tässä artikkelissa elettyinä sosiaalisina suhteina, ei abstrakteina tai staattisina positioina, ja niihin sisältyy myös jännitteitä ja neuvottelua (Skeggs 1997; Reay 2005, 2006; Ojala 2010). Sosiaaliset erot materialisoituvat eri tavoin arvostettuina sosiaalisina, kulttuurisina ja taloudellisina resursseina, jotka puolestaan asettavat yksilöt hierarkkisesti rakentuviin kategorioihin (ks. Anthias 2005; Skeggs 1997). Koulun ylläpitämät kulttuuriset käytännöt tuottavat ikään, sukupuoleen ja sosiaaliluokkaan liittyviä koulutettavuuden sosiaalisia eroja (ks. Tolonen 2008).
Siirryn seuraavaksi tarkastelemaan iän ja siihen kietoutuvien sukupuolen, sosiaaliluokan ja koulutettavuuden suhteen rakentuvia ristiriitoja ja sosiaalisia eroja kolmen viisikymppisen ja neljän kuusikymppisen aikuislukiosta valmistuneen naisen haastatteluin tuotetuissa narratiivisissa elämänhistorioissa. Tarkastelen naisten kerrontaa erillisissä tulosluvuissa. Luettavuuden parantamiseksi poistin täytesanat ja toistot aineistoesimerkeistä ja merkitsin sulkujen sisällä olevalla kolmella pisteellä (...). Pidemmät aineistoesimerkit olen jaotellut puhujalle ominaista puheen rytmiä, rakennetta ja merkityksenantoa ilmentämään. Taulukossa 1 esitän yhteenvedon artikkelin aineistona olevien haastateltavien sosiaalisista taustoista, koulutuspoluista ja työurista.

\section{AIKUISLUKIO REVANSSINA JA MAHDOLLISUUTENA TASOITTAA PELI}

Tutkimukseen osallistuneiden viisikymppisten Kaarinan (49), Jaanan (48) ja Leenan (54) koulutukselle antamat merkitykset heijastelevat Ari Antikaisen ja hänen kollegoidensa (Antikainen \& Huotelin 1996) määrittelemän rakennemuutoksen ja lisääntyvien koulutusmahdollisuuksien sukupolven (vuosina 1936-1955 syntyneet) kokemuksia. Koulutus ja työ ovat kietoutuneet läheisesti yhteen ja koulutuksen merkitys on ollut pääasiassa välineellinen. Perheen taloudellinen tilanne on kuitenkin saattanut katkaista koulutien kuten Leenan nuoruudessa. Hän suoritti nuoruudessaan keskikoulun, mutta perheen taloudellisesta tilanteesta johtuen hän ei voinut jatkaa lukio-opintoihin, vaan siirtyi työelämään 15-vuotiaana. Leenalle koulutus näyttäytyy myös tavoittamattomana ideaalina kuten vanhimman sodan ja niukkojen koulutusmahdollisuuksien koulutussukupolvelle (mt.): "Kaipasin kuitenkin joka syksy kouluun."

Kaarina suoritti nuoruudessaan kolmivuotisen kokeiluperuskoulun, mutta ei viihtynyt koulussa ja kertoo kapinoineensa järjestelmää vastaan "väärillä keinoilla semmosel hillumisella". Hän kertoo päättäneensä koulun loputtua, että " mä en (...) ikinä enää avaa koulun ovia". Työväenluokkaisessa kodissa kasvaneelle Kaarinalle tämä tarkoitti, että peruskoulun jälkeiset koulutusmahdollisuudet rajoittuivat Mari Käyhkön (2006) tutkimien työläistyttöjen tavoin 
Taulukko1. Yhteenveto haastateltavien sosiaalisista taustoista, koulutuspoluista ja työurista.

\begin{tabular}{|c|c|c|c|c|}
\hline Haastateltava & Ikä & Sosiaalinen tausta & Koulutuspolku & Työura \\
\hline Kaarina & 49 & $\begin{array}{l}\text { työväenluokkainen lapsuus } \\
\text { pikkukaupungissa, isä kuoli } \\
\text { tapaturmaisesti Kaarinan } \\
\text { ollessa } 5 \text { v. }\end{array}$ & $\begin{array}{l}\text { kansalaiskoulu, } \\
\text { kokeiluperuskoulu, talouskoulu } \\
\text { (4.5 kk), ammattikoulu (1 v.), } \\
\text { työnantajan tarjoamat kurssit, } \\
\text { aikuislukio }\end{array}$ & $\begin{array}{l}\text { asiantuntijatehtäviin eteneminen } \\
\text { koulutuksen ja työssä oppimisen } \\
\text { kautta, vakinaisessa työsuhteessa }\end{array}$ \\
\hline Leena & 54 & $\begin{array}{l}\text { kaupunkilapsuus, } \\
\text { vanhempien ero, } \\
\text { taloudellisesta tilanteesta } \\
\text { johtuen keskeytti koulun } \\
\text { 15-vuotiaana }\end{array}$ & $\begin{array}{l}\text { kansakoulu, keskikoulu, } \\
\text { iltakeskikoulu, aikuislukio }\end{array}$ & $\begin{array}{l}\text { 15-vuotiaana töihin, } 38 \text { vuotta } \\
\text { saman yrityksen palveluksessa, } \\
\text { epävarmuus työsuhteen } \\
\text { jatkumisesta }\end{array}$ \\
\hline Jaana & 48 & $\begin{array}{l}\text { lapsuus kaupungissa, } \\
\text { vanhemmat arvostivat } \\
\text { koulutusta }\end{array}$ & $\begin{array}{l}\text { keskikoulu, lukio keskeytyi } \\
\text { ehtoihin, ammattikoulutus, } \\
\text { aikuislukio }\end{array}$ & $\begin{array}{l}\text { ammatissa yli } 20 \text { vuotta, } \\
\text { suunnittelee alan vaihtoa } \\
\text { terveyssyistä }\end{array}$ \\
\hline Pirkko & 60 & $\begin{array}{l}\text { vaatimattomasta } \\
\text { kaupunkikodista, äiti } \\
\text { yksinhuoltaja }\end{array}$ & $\begin{array}{l}\text { kansakoulu, iltakeskikoulu, } \\
\text { ammattikoulutus, aikuislukio }\end{array}$ & $\begin{array}{l}\text { useita eripituisia työsuhteita, } \\
\text { eläkkeelle uupumuksen takia }\end{array}$ \\
\hline Roosa & 64 & $\begin{array}{l}\text { kaupunkikodista, jossa } \\
\text { taloudellisesti niukkaa }\end{array}$ & $\begin{array}{l}\text { keskikoulu, } 1 \text { vuosi lukiota } \\
\text { nuoruudessa, työssä } \\
\text { oppiminen, ammattiajolupa } 160 \\
\text { v.), aikuislukio }\end{array}$ & $\begin{array}{l}\text { työtehtävissä eteneminen hyvään } \\
\text { ammattiasemaan, } 58 \text {-vuotiaana } \\
\text { eläkkeelle uupumuksen takia }\end{array}$ \\
\hline Sara & 66 & $\begin{array}{l}\text { Karjalan evakko, } \\
\text { pienviljelijäperheestä, äiti } \\
\text { yksinhuoltaja }\end{array}$ & $\begin{array}{l}\text { kansakoulu, työhön liittyviä } \\
\text { kursseja, iltakeskikoulu, } \\
\text { aikuislukio }\end{array}$ & $\begin{array}{l}\text { 16-vuotiaasta erilaisissa } \\
\text { töissä, kotiäitinä lasten ollessa } \\
\text { pieniä, 52-vuotiaana eläkkeelle } \\
\text { uupumuksen takia }\end{array}$ \\
\hline Kaija & 60 & pienviljelijäperheestä & $\begin{array}{l}\text { kansalaiskoulu, toimistokurssi } \\
\text { (n.6 kk), työssä oppiminen, } \\
\text { peruskoulu ja lukio } \\
\text { aikuislukiossa }\end{array}$ & $\begin{array}{l}\text { nuoresta asti mm. toimistotöissä, } \\
\text { 19-vuotta saman työnantajan } \\
\text { palveluksessa, kärsi } \\
\text { työuupumuksesta ja vaihtoi } \\
\text { työpaikkaa, edelleen työelämässä }\end{array}$ \\
\hline
\end{tabular}

niin sanottuun "b-luokan" koulutukseen vastakohtana arvostetulle akateemiselle koulutukselle, johon lukion suorittaminen olisi avannut portin. Toisin kuin Kaarina Jaana jatkoi keskikoulusta lukioon, jonka kuitenkin keskeytti, kun koulunkäynti oli motiivien puuttuessa pelkkää "pakkopullaa". Molemmat siirtyivät heti koulun jälkeen työelämään ja hankkivat myöhemmin käytännön ammatin naisvaltaiselta alalta. Molemmat myös aloittivat myöhemmin iltalukion tai aikuislukion, jonka kuitenkin keskeyttivät.

Tutkimuksen viisikymppisille naisille aikuislukio tarjoaa "revanssin" ja mahdollisuuden "tasoittaa peli", kuten Kaarina asian ilmaisee. Peruskouluaika oli jäänyt kaivertamaan Kaarinan mieltä "semmosena suurena epäonnistumisena". Myös Jaana kertoo aikuislukion uudelleen aloittaessaan päättäneensä, että "nyt en enää vedä puihin". Harrastuksena alkaneet opinnot olivat muuttuneet opintojen edetessä haasteeksi ja tavoitteeksi saavuttaa "se valkoinen lakki". Myös Leenalle valkolakki oli pitkäaikaisen unelman täyttymys: "Ku mä katon tonne suuntaan ni (...) siel on mun koulu, jonne mä meen tänään hakee valkolakkini."

Haastatteluhetkellä Kaarina, Leena ja Jaana olivat vakinaisessa työsuhteessa. Kaarina asiantuntijatehtävissä, Leena saman työnantajan palveluksessa jo 38-vuotta ja Jaana ammatissa, jota oli harjoittanut 20-vuotta. Aikuislukio innosti opiskeluun ja sytytti kipinän myös jatko-opintoihin ja uuteen uraan. Lukion päättötodistus ja ylioppilastutkinto merkitsee porttia kohti jotakin uutta, kuten Kaarina toteaa: "Tää on tämmönen välivaihe nyt" ja "et mä voin pyrkii nyt sillä paperilla (... ) minne vaan". Hän kertoo lähettäneensä hakupaperit ammattikorkeakouluun ja haaveilee päätoimisesta opiskelusta ja työtehtävien tai alan vaihdosta ja niiden mahdollistamasta korkeammasta sosiaalisesta asemasta. Leena pelkää menettävänsä 
työpaikkansa ikänsä vuoksi: "Nykyinen työ on kuitenkin semmosta että siel ei tän ikäsiä ihmisiä oikeestaa katota enää" (vrt. Ruoholinna 2011). Hän suunnittelee hankkivansa tutkinnon, jolla varmistaa työllisyytensä myös tulevaisuudessa. Jaana haluaa myös kouluttautua uuteen ammattiin osin terveyssyistä.

\section{VALKOINEN LAKKI JA VOI SANOA ETTÄ EI 00 ENÄÄ TYHMÄ}

Aineiston viisikymppiset naiset kertovat negatiivisista koulukokemuksista ja heille kaikille on iskostunut käsitys itsestä huonona tai tyhmänä oppilaana lapsuuden ja nuoruuden kouluajoilta (vrt. Räty \& Snellman 1998). Jaana kertoo, että "ei sillä tavalla oo kauheesti uskonu itseensä", mikä on myös vaikuttanut tehtyihin koulutusvalintoihin ja omaan koulutuspolkuun. Aikuislukiossa naiset joutuvat uudelleen pohtimaan omaa kykyään opiskelijana ja oppijana, kun tulevat uudelleen arvioiduksi koulun ylläpitämin arviointikriteerein. Lukion päättötodistus ja ylioppilastutkintotodistus ovat kuitenkin osoitus siitä, että "jotain muutosta on tapahtunu" ja "voi sanoa että ei oo enää tyhmä (...) ainakaan niin tyhmä", kuten Leena toteaa. Kaikki kolme viisikymppistä naista ovat myös tehneet pitkän työuran ja edenneet työtehtävissä. Kaarina kertoo, kuinka hän on "ammatillisis opinnois menestyny loistavasti ja työelämässä erittäin hyvin". Kuitenkaan ammattikoulun linjalta "ei mitään tutkintotodistust tullu ku se on tietysti ammatillinen koulu et ei sillai sil [tutkinnolla] ei ollu oikee mitä̈n nimee". Formaalin tutkinnon puute täytyy korjata ja osoittaa työelämässä ja muualla kertynyt osaaminen muodollisella tutkinnolla.

Kaarinan kerronnassa formaali tutkinto kiinnittyy valkoiseen lakkiin. Aikuislukio-opinnot ovat haaste ja mahdollisuus osoittaa oma pätevyys opiskelijana ja oppijana:

Et ku mä sit tarpeeks monta kertaa sanoin työkaverille että ku mä en nyt sitte ku mä en nyt sit lukiotakaan loppuun käynny ja ku ei mul oo nyt oikeen mitään täs niinku tämmöst kunnon tutkintookaa ja ku en mä nyt sit sitä lukiotakaan sit käynny. (...) Ja miks mä sit käyn sen?

No mä haluun sen lakin. No mitä sillä lakilla tekee? Ei mitään (naurua), siel se on pölyttymässä jos ei haluu vappuna panna päähän. Mut että jotain sellasta et mä halusin niinku tavallaan haastaa itteni siihen et kylhän sä nyt siihen pystyt jos sä haluat et näytä nyt ittelles et pystyt sä vai et tai sit pitää lakkaa vinkumasta että ei sitä voi koko elämäänsä niinku jotain aatella et voiku olis sitä tai tätä että. Ni se nousi jotenki sellaseks.

(Kaarina, 48 vuotta)

\section{AIKUISLUKIO "TÄSSÄ IÄSSÄ"}

Pirkon (60), Roosan (64), Saran (66) ja Kaijan (60), tutkimukseen osallistuneiden kuusikymppisten naisten kokemukset heijastavat Antikaisen ja hänen kollegoidensa (Antikainen \& Huotelin 1996) määrittelemää kahta vanhinta koulutussukupolvea: 1) sodan ja niukkojen koulutusmahdollisuuksien sukupolvi (ennen vuotta 1935 syntyneet), 2) rakennemuutoksen ja lisääntyvien koulutusmahdollisuuksien sukupolvi (vuosien 1936-1955 syntyneet). Kuten vanhimmalle koulutussukupolvelle koulutus näyttäytyy Saralle ja Kaijalle ideaalina, koska se oli vaikeasti saavutettavissa. Työnteko oli keskeisellä sijalla heidän elämässään jo lapsena ja sotakokemukset vaikuttivat myös kokonaisvaltaisesti Saran elämään. Pirkolle ja Roosalle koulutus ei näyttäydy samalla tavoin ideaalina, sillä heidän nuoruudessaan koulutusmahdollisuudet olivat jo lisääntyneet kaupungeissa. Työ on ollut keskeisellä sijalla heidän elämässään ja oppimisella ja opiskelulla eri oppimiskonteksteissa välineellinen arvo, mikä heijastaa rakennemuutoksen ja lisääntyvien koulutusmahdollisuuksien sukupolven kokemuksia.

Kaikki neljä kuusikymppistä naista ovat etsineet tilaisuuksia oppia läpi elämänsä: ensin kansakoulussa, myöhemmin erilaisilla kursseilla, työssä, harrastuksissa ja matkoilla sekä aikuislukiossa. Myös kaikki neljä kertoivat, että olivat kärsineet työuupumuksesta työuran loppupuolella, mikä oli myös johtanut Pirkon, Roosan ja Saran kohdalla varhaiseen eläkkeelle siirtymiseen. Kaija oli siirtynyt uuden työnantajan palvelukseen, mutta ei näe, että opiskelusta on hänelle hyötyä työmarkkinoilla: "Mul on hirveen vaikee saada työtä enää täs iäs, vaikka mä osaisin kuinka paljon olis kokemusta takana."

Tutkimuksen kuusikymppisten naisten asema 
työelämän reunamille tai eläkkeellä asettaa heidät myös elinikäisen oppimisen reunamille. Kuten Ojala (2005) kirjoittaa, kaikille tasa-arvoisia oppimismahdollisuuksia korostava elinikäinen oppiminen pikemminkin lisää kuin vähentää ikään ja yksilön työmarkkina-asemaan kiinnittyvää epätasa-arvoa. Elinikäisen oppimisen reunamilla oppimista rohkaistaan pelkästään sosiaalisena toiminnan muotona ja mielekkäänä tekemisenä eikä tutkintotavoitteiseen opiskeluun kannusteta. Tämä tulee esiin erityisesti Saran ja Kaijan kerronnassa. Koulutuksen formaalit merkit kuten arvosanat ja tutkinnot eivät ole heille tärkeitä, vaan opiskelu "oli tavallaan huvin vuoks" ja toi säännöllisyyttä elämään. Ylioppilastodistuksen saatuaan Sara kertoo hämmästyneensä, että "se ei tuntunu miltään", "kauheen hienolta tai tämmöseltä näin". Lukiossa opettajat painottavat ylioppilaskirjoituksissa menestymistä; se oli tärkeää myös Saralle, muttei ainoa syy lukioopinnoille. Sekä Sarasta että Kaijasta piirtyy kuva uteliaina
ELINIKÄINEN

OPPIMINEN ON

I990-LUVULTA ALKAEN

KIINNITTYNYT ENNEN

MUUTA TALOUDELLISIIN

MOTIIVEIHIN. ja tiedonhaluisina oppijoina, joille itse oppiminen on tärkeämpää kuin hyvät arvosanat. Kuusikymppisinä he ovat vapautuneet opiskelemaan sitä, mikä itseä kiinnostaa. Molemmat kuitenkin pärjäsivät hyvin lukiossa, kun siellä "väkisinkin oppii kaikkea".

Asema työelämän reunamilla ei kuitenkaan yksin märitä oppimiselle ja opiskelulle annettuja merkityksiä, vaan myös elämänkulussa syntyneet subjektiiviset merkitykset määrittävät niitä. Saran ja Kaijan tavoin myös Pirkko korostaa itseä kiinnostavien aineiden, psykologian ja filosofian opiskelua, joita aina tarvitsee elämässä. Hänelle kuitenkin aikuislukio tarjoaa "tässä iässä" mahdollisuuden nuorena ohi livahtaneisiin teoreettisin ja akateemisiin opintoihin, vaikkakin "40 vuotta (...) jälkijunassa". Sekä Pirkolle että Roosalle on itse oppimisen lisäksi tärkeää osoittaa kykynsä ja osaamisensa arvosanoin ja tutkinnoin. Pirkko toteaa, että "se lukion päästötodistus se oli tärkee"; "ei oo käynny sitä koulua ellei ole päästötodistusta". Hän oli haastatteluhetkellä valmistautumassa yliopis- ton pääsykokeisiin ja pohti myös avoimen yliopistoopiskelun mahdollisuutta.

Roosalle tutkintotavoitteinen opiskelu aikuislukiossa "täytti sen semmosen tyhjän (...) tilan", joka oli syntynyt työuupumuksen ja eläkkeelle siirtymisen myötä. Häntä motivoi lukion päättötodistuksen ja ylioppilastutkinnon suorittamisessa "semmonen tietty kokonaisuus" ja opiskelun tavoitteellisuus verrattuna yksittäisten kurssien suorittamiseen. Tavoitteellinen opiskelu osoitti, että työelämän "epäonnistumisesta" huolimatta hän on pätevä ja "työllistettävissä", vaikka ei enää työssä (vrt. Brine 2006). Roosa näkee kuitenkin eron oman ja nuorempien opiskelun välillä: "Se ei ollu mulle mikään välttämätön paha eikä edellytys mun elämäni onnistumiselle tai tulevaisundelle." Opiskelu on vanhempana vähemmän merkityksellistä, mutta samalla myös helpompaa kuin nuorille, joilla työura on vielä edessä.

\section{VOIKS NÄIN VANHAT TULLA TÄNNE KOULUUN?}

Sekä Pirkon että Roosan kerronnassa voi tunnistaa ikään liittyviä koulutettavuuden eroja heidän neuvotellessaan aikuislukio-opintojen aloittamisesta. Pirkko kuvaa epävarmuuden, pelon ja häpeän tuntemuksiaan, kun hän ensimmäistä kertaa varovasti hiippaillen tuli koulurakennukseen: "Mähän vähän niinku et ujona, että voiskohan näin vanha tulla viel opiskelemaan"; "enhän mä tienny vaikka täällä ois ollu viidenkympin ikärajat, et ei tänne saa tullakaan (...) yli-ikäset, en mä tienny sellasta (...) et se oli ihan uus asia mulle että et todella vanhat ja nythän (...) mä tiedän sen, et ei mua hävetä yliopistoonkaan". Tunteet kietoutuvat Pirkon kerronnassa ikään ja sosiaaliseen asemaan hänen neuvotellessa aikuislukio-opintojen aloittamisesta (vrt. Reay 2005). Opiskelu aikuislukiossa on kuitenkin tuonut Pirkolle varmuutta jatkaa opintoja korkeimmassa akateemisessa opinahjossa yliopistossa.

Myös Roosalla oli ikään liittyvä "ennakkoluu10" aikuislukio-opintoja pohtiessaan: "No hyvänen aika mä oon yli kuuskymmentä ja eläkkeellä ja lä- 
hen jotain lukioo suorittaa, mikä nyt on perinteisesti nuorten ihmisten koulutusta. Se siinä oli ei kai siinä muuta ollu." Aikuislukion rehtori kuitenkin toivotti molemmat kuusikymppiset naiset tervetulleeksi lukioon: "Hän sai mut sit innostuu et totta kai sä voit et onhan tä̈l nyt vanhempiaki ihmisiä"

\section{VOIKS NÄIN VANHAT TULLA TÄNNE KOULUUN?}

Vanha opiskelija kohtaa herkästi ihmettelyä, kuinka voin oppia jotakin vielä 'näin vanhana'. Mutta kuten Roosa toteaa: "Oppiminen sujui luontevasti vaikka edellisistä opinnoista oli 45 vuotta." Toisaalta myös kuusikymppiset naiset itse kertovat oppimisen hidastuneen ja muistin alkaneen pätkiä iän myötä (vrt. Tikkanen 2003). Kaija arvioi, että kielten opiskelussa täytyy tehdä kolme kertaa enemmän töitä kuin nuorempana.

Naiset kuitenkin painottavat, että elämänkokemuksesta on ollut aikuislukio-opinnoissa hyötyä. Sara toteaa: "Ikä ei mielestäni kuitenkaan ole mikään miinuspuoli" ... "Elämäni ei ole ollut 'tyhjä taulu' aloittaessani opiskelun." Kuten Susanna Paloniemen (2004) haastattelemat työntekijät myös Roosa arvioi erityisesti työkokemuksen hyödylliseksi esimerkiksi yhteiskuntaopissa: "Et mullehan on päivänselvä et miten valitaan, miten vaaleissa menetellään. Mähän oon niinku työssäniki jo joutunu tarviin sitä ja kaikki niinku tämmöset asiat et sillä lailla kokemuksest on ollu hyötyy." Pirkko näkee nuorten ja vanhempien opiskelijoiden vahvuudet aikuislukion rikkautena: "No meillä vanhoillahan on sitä elämänkokemusta mitä nuoret taas tarvii (... ) ja niil on taas peruskoulu tossa nurkan takana ni (... sehän oli puolin ja toisin hyödyllistä."

Matematiikka, ja erityisesti pitkä matematiikka, rakentuu aineistossa maskuliinisena älykkyyden prototyyppinä ja menestys matematiikassa luonnollisempana miehelle kuin naiselle, nuorelle kuin vanhalle (esim. Räty, Kasanen \& Kärkkäinen 2006; Siivonen 2012). Elina Lahelma (2004) on myös todennut, että tyttöjen menestystä matematiikassa selitetään kovalla työllä, ei luonnollisella lahjakkuudella. Pirkon ja Roosan kerronnassa matematiikan oppimisen sukupuolittuneisuus kietoutuu ikään heidän pohtiessaan omaa kykyään oppia matematiikkaa vanhoina naisina. Molemmat myös neuvottelevat lyhyen ja pitkän matematiikan valinnan välillä. Alla olevassa katkelmassa Roosa ja aikuislukion (nais) rehtori tulkitsevat 60-vuotiaan naisen pitkän matematiikan valinnan kulttuurisesti jaettuna vitsinä, jolle he voivat yhdessä nauraa:

Mä muistan viel ku siinä naureskeltiin jotenki sitä $k u$ katottii niit aineita, $k u$ mä sanoin sillo et mä lyhyen matikan otan. Ja me naureskeltii joo et jos vaikka otatki pitkän matikan. Mä sanoin et heh heh kyllä varmaa ja niin siin kävi et mä sen otin sitte. (Roosa, 64 vuotta)

Roosa korostaa joutuneensa tekemään eniten töitä juuri matematiikassa, mutta myös kokeneensa eniten tyydytystä suoritettuaan menestyksekkäästi pitkän matematiikan kurssit. Hän arvioi, että "ehkä (...) miehille luonnistuu tommonen joku matematiikan opiskelu (...) vanhempanakin (...) paremmin ku naisille". Ikään ja sukupuoleen liittyvien normien rikkominen ja pitkän matematiikan kurssien suorittaminen menestyksekkäästi "64-vuotiaana mummina" näyttäytyy poikkeuksellisena ja suurena ylpeyden aiheena. Se on se "pointti" ja "aika hyvä juttu".

\section{PARASTA ENNEN}

Aikuislukiosta valmistuneet viisikymppiset ja kuusikymppiset naiset ovat vastanneet "uuden aikuisuuden" haasteeseen (Koski \& Moore 2001) ja pyrkineet elämänsä aikana jatkuvasti oppimaan uutta ja kehittämään itseään eri tavoin työssä ja koulutuksessa. Aikuislukio on tarjonnut mahdollisuuden revanssiin: osoittaa oma kyky oppijana ja opiskelijana - myös maskuliiniseksi määrittyvässä matematiikassa - sekä toteuttaa unelma valkoisesta lakista ja sen tuomasta korkeammasta sosiaalisesta asemasta. Vastoin elinikäisen oppimisen ideaalia kaikkia koskevasta koulutettavuudesta tutkimus kuitenkin vahvistaa, että kaikilla ei ole iästään, sosiaalisesta asemastaan ja sukupuolestaan johtuen samanarvoisia mahdollisuuksia oppia ja kouluttautua (ks. esim. Lahelma 2004; Reay 2006; Räty \& Snellman 1998).

Ylioppilastutkinto saa erilaisia merkityksiä viisikymppisten ja kuusikymppisten naisten kerronnassa. Viisikymppiselle Kaarinalle, Jaanalle ja Leenalle se avaa legitiimin elinikäisen oppijan statuksen ja mah- 
dollisuuden jatko-opintoihin ja uuteen uraan. Pitkän työuran jälkeenkään he eivät suunnittele varhaista eläkkeelle siirtymistä. Elinikäisen oppimisen ja kouluttautumisen merkitys on välineellinen ja kietoutuu työhön ja uuden uran rakentamiseen.

Tutkimuksen kuusikymppisille naisille Pirkolle, Roosalle, Kaijalle ja Saralle ylioppilastutkinnon suorittaminen on myös ylpeyden aihe, mutta lukio-opinnot merkityksellistyvät pikemminkin harrastuksena ja mahdollisuutena itsensä sivistämiseen. Heidän opiskelunsa ei näyttäydy samalla tavalla arvokkaana kuin aktiivisesti työelämässä olevien viisikymppisten naisten. He asettuvat paitsi työelämän myös elinikäisen oppimien reunamille ja takapihalle. Heitä kyllä rohkaistaan oppimaan ja opiskelu nähdään sosiaalisen toiminnan muotona ja mielekkäänä tekemisenä, mutta ei heille enää yhteiskunnallisesti merkityksellisenä toimintana (vrt. Ojala 2005; 2010). Oppiminen muodostuu osaksi yksilöllistä elämänhallintaa, ei yhteiskunnallisen osallistumisen edistämistä. Myöhemmän iän ja työelämän ulkopuolista opiskelua ei edelleenkään arvosteta, eivätkä mahdollisuudet elinikäiseen oppimiseen ja opiskeluun ole kaikille samat (vrt. Tikkanen 2003).

Tutkimus nostaa esiin useita ikään, oppimiseen ja koulutettavuuteen liittyviä paradokseja. Elinikäiseen oppimiseen kannustetaan kaikkia kehdosta hautaan. Tämä nähdään sekä mahdollisuutena että pakkona jatkuvien muutosten ja uhkien keskellä. Kulttuuriset ikään liittyvät normit kuitenkin määrittävät, millainen oppiminen ja kouluttautuminen on kulloinkin suotavaa ja mahdollista ja millaisia odotuksia kuhunkin ikään kohdistuu (Aapola 1999ab, Ojala 2005, 2010). Myös oma paikka kykyjen sukupuolittuneessa ja sosiaalisessa hierarkkiassa opitaan jo lapsena ja se määrittää tutkimukseen osallistuneiden käsityksiä omasta oppimiskyvystä myös aikuisuudessa (Siivonen 2010a).

Tutkimukseen osallistuneet kuusikymppiset naiset ovat oppineet arvostamaan erityisesti elämänlaajuista oppimista erilaisissa oppimisympäristöissä - nonformaaleja kursseja työelämässä, aikuiskoulutuksessa tai harrastuksissa tai informaalia arkielämän oppimista formaalin koulutuksen rinnalla. Itse oppiminen on heille tärkeämpää kuin arvosanat ja suoritukset. Viisikymppisille jatko-opintoja ja uutta uraa suunnitteleville naisille työelämässä hankittu osaaminen näyttäytyy merkityksellisenä toimintana kuitenkin vasta, kun se on formaalilla tutkintotodistuksella osoitettu (Tushling \& Engemann 2006, ks. myös Olssen, 2006). Elinikäisen oppimisen tavoite joustavan, sopeutuvan ja työllistettävän työvoiman riittävyyden takaamiseksi yhtälailla elinikäistä kuin elämänlaajuista oppimista hyödyntäen ei tämän tutkimuksen valossa kuitenkaan näytä toteutuvan.

Keskustelu työurien pidentämisestä koskettaa tutkimukseni pohjalta erityisesti viisikymppisiä työntekijöitä. Myös Eeva-Leena Vaahtion (2003) konstruoima työmarkkinaikä asettuu hänen tekemänsä rekrytointitutkimuksen perusteella 55 vuoden ikään. Osallistuminen aikuiskoulutukseen myös vähenee merkittävästi 55. ikävuoden jälkeen (mt.). Kuusikymppisillä on tutkimukseni perusteella kyllä mahdollisuus itsensä sivistämiseen ja itseä kiinnostavien asioiden opiskeluun, mutta marginaalissa ja sivussa työmarkkina-aseman perusteella määrittyvästä elinikäisen oppimisen keskuksesta. Parasta ennen päivämäärä oppijana ja opiskelijana näyttäisi olevan jo ohi.

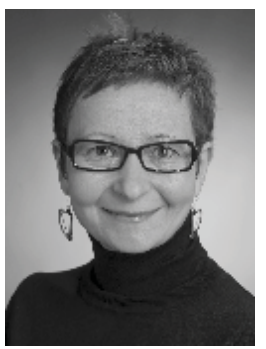

Päivi Siivonen

FT, tutkijatohtori Opettajankoulutuslaitos, Helsingin yliopisto 


\section{LÄHTEET}

Aapola, S. (1999a). Ikä, koulu ja sukupuoli: Peruskoulun kulttuuriset ikäjärjestykset. Teoksessa Tolonen T. (toim.) Suomalainen koulu ja kulttuuri. Tampere: Osuuskunta Vastapaino, 231-246.

Aapola, S. (1999b). Murrosikä ja sukupuoli: Julkiset ja yksityiset ikämäärittelyt. Suomalaisen Kirjallisuuden Seuran Tutkimuksia 763. Nuorisotutkimusverkosto Nuorisotutkimusseura Julkaisuja 9/99. Helsinki: Suomalaisen Kirjallisuuden Seura.

Aapola, S. (2002). Exploring dimensions of age in young people's lives: A discourse analytical approach. Time \& Society 11(2/3), 295-314.

Alheit, P., \& Dausien, B. (2002). Lifelong learning and 'biographicity': Two theoretical views on current educational changes. In Bron A. \& Schemmann M. (Eds.) Social science theories in adult education research. Münster: LIT Verlag, 211-241.

Anthias, F. (2005). Social stratification and social inequality: Models of intersectionality and identity. In Devine F., Savage M., Scott J., \& Crompton R. (Eds.) rethinking class. culture, identities \& lifestyles. Houndmills: Palgrave Macmillan, 24-45.

Antikainen, A., \& Huotelin, H. (toim.). (1996). Oppiminen ja elämänhistoria. Aikuiskasvatuksen 37. vuosikirja. Kansanvalistusseura ja Aikuiskasvatuksen tutkimusseura. Helsinki: BTJ Kirjastopalvelu.

Bamberg, M., \& Georgakopoulou, A. (2008). Small stories as a new perspective in narrative and identity analysis. Text \& Talk 28-3, 377-396.

Boden, R., \& Nevada, M. (2010). Employing discourse: Universities and graduate 'employability'. Journal of Education Policy 25, 37-54.

Brine, J. (2006). Lifelong learning and the knowledge economy: Those that know and those that do not the discourse of the European Union. British Educational Research Journal 32(5), 649-665.

Brown, P., Hesketh, A., \& Williams, S. (2003). Employability in knowledge-driven society. Journal of Education and Work 16, 107-126.

Brunila, K. (2009). Parasta ennen - Tasa-arvotyön projektitapaistuminen. Kasvatustieteen laitoksen tuktimuksia 222. Helsinki: Yliopistopaino.

Ernest, P. (1998). Introduction: Changing views of "the gender problem' in mathematics. In Walkerdine V., Counting girls out: Girls and mathematics. London: Falmer Press, 1-14.

Euroopan yhteisöjen komissio. (2000). Komission yksiköiden valmisteluasiakirja: Elinikäinen oppiminen. Bryssel.

Fejes, A. (2005). New wine in old skins: Changing patterns in the governing of the adult learner in Sweden. International Journal of Lifelong Education 24(1), 71-86.
Fejes, A. (2006). The planetspeak discourse of lifelong learning in Sweden: What is an educable adult? Journal of Educational Policy 21(6), 697-716.

Filander, K. (2006). Työ, koulutus ja katoavat ammattiidentiteetit. Teoksessa Mäkinen J., Olkinuora E., Rinne R. \& Suikkanen A. (toim.) Elinkautisesta työstä elinikäiseen oppimiseen. Jyväskylä: PS-kustannus, 43-59.

Häyrynen, Y-P., \& Hautamäki, J. (1973). Ihmisen koulutettavuus ja koulutuspolitiikka. Helsinki: Weilin+Göös.

IKLO, Iltakoulujen liitto. (2007). http://www.aikuislukiot.fi/ IKOMI, Ikääntyvät työelämässä. (1996). Ikääntyvien työllistymisedellystysten parantamista selvittäneen komitean mietintö. Komiteamietintö 1996:14. Helsinki: Työministeriö.

Komulainen, K. (1998). Kotihiiriä ja ihmisiä: Retorinen minä naisten koulutusta koskevissa elämänkertomuksissa. Joensuun yliopiston yhteiskuntatieteellisiä julkaisuja 35. Joensuu: Joensuun yliopisto.

Korvajärvi, P. (1999). Ikäsyrjinnän kokemukset ja käytännöt työelämässä. Teoksessa Kangas I. \& Nikander P. (toim.) Naiset ja ikääntyminen. Helsinki: Gaudeamus, 85-105.

Koski, L., \& Moore, E. (2001). Näkökulmia aikuisuuteen ja aikuiskasvatukseen. Aikuiskasvatus 21(1), 4-13.

Kuusinen, J. (2003). Älykkyys ja vanheneminen. Teoksessa Heikkinen, E. \& Rantanen, T. (toim.) Gerontologia. Tampere: Duodecim, 164-173.

Käyhkö, M. (2006). Siivoojaksi oppimassa: Etnografinen tutkimus työläistytöistä puhdistuspalvelualan koulutuksessa. Joensuu: Joensuu University Press.

Lahelma, E. (2004). Tytöt, pojat ja koulukeskustelu: miten koulutuspoliittiset ongelmat rakentuvat? Teoksessa Vitikka E. (toim.) Koulu-SukupuoliOppimistulokset. Opetushallitus, Moniste 8/2004. 54-67.

Linde, C. (1993). Life stories: The creation of coherence. New York: Oxford University Press.

Ojala, H. (2005). Ikääntyneenä naisena opiskelemassa - hyödyn ja sivistyksen rajankäyntiä. Teoksessa Mietola R., Lahelma E., Lappalainen S., \& Palmu T. (toim.) Kohtaamisia kasvatuksen ja koulutuksen kentillä: Erontekoja ja yhdessä tekemistä. Turku: Suomen kasvatustieteellinen seura, 51-66.

Ojala, H. (2010). Opiskelemassa tavallaan. Vanhat naiset ikäihmisten yliopistossa. Tampere: Tampere University Press.

OPM, Opetusministeriö. (2006). Aikuisten perusopetuksen ja lukiokoulutuksen kehittämisohjelmaehdotus vuosiksi 2007-2012. 
Opetusryhmämuistioita ja selvityksiä 2006:33. http://www.minedu.fi/export/sites/default/OPM/ Julkaisut/2006/liitteet/tr33.pdf?lang=fi

Olssen, M. (2006). Understanding the mechanisms of neoliberal control: Lifelong learning, flexibility and knowledge capitalism. International Journal of Lifelong Learning Education 25(3), 213-230.

Paloniemi, S. (2004). Ikä, kokemus ja osaaminen työelämässä. Työntekijöiden käsityksiä iän ja kokemuksen merkityksestä ammatillisessa osaamisessa ja sen kehittämisessä. Jyväskylä Studies in Education Psychology and Social Research 253. Jyväskylä: Jyväskylän yliopisto.

Reay, D. (2005). Beyond consciousness? The psychic landscape of social class. Sociology 39(5), 911-928.

Reay, D. (2006). The zombie stalking English schools: Social class and educational inequality. British Journal of Educational Studies 54(1), 288-307.

Ruoholinna, T. (2011). Kaupanalan muutos ikääntyvien silmin. Aikuiskasvatus 2(31), 84-96.

Räty, H. (2001). Lusikasta haarukaksi: Koulun ja koulutuksen sosiopsykologinen näkökulma. Psykologia 36, 342-347.

Räty, H., Kasanen, K., \& Kärkkäinen, R. (2006). School subjects as social categorisations. Social Psychology of Education 9, 5-25.

Räty, H., \& Snellman, L. (1998). Social representations of educability. Social Psychology of Education 1. 359-373.

Skeggs, B. (1997). Formations of class and gender: Becoming respectable. London: SAGE.

Siivonen, P. (2010a). From a "student" to a lifelong "consumer" of education? Constructions of educability in adult students' narrative life histories. Research in Educational Sciences 47. Jyväskylä: Finnish Educational Research Association.

Siivonen, P. (2010b). Tutkintoja ja itsensä sivistämistä -kertomuksia aikuislukiosta. Aikuiskasvatus 3(30), 196-205.

Siivonen, P. (2012). "A bad head for maths"? Constructions of Educability and Mathematics in Adult Students' Narrative Life Histories. Scandinavian Journal of Educational Research, 1-19 (iFirst Article).
Tikkanen, S. (2003). Elinikäinen oppiminen elämänhallintaa ja ihmisenä kasvua. Teoksessa Heikkinen, E. \& Rantanen, T. Gerontologia. Tampere: Duodecim, 408-417.

Tolonen, T. (2008). Yhteiskuntaluokka: menneisyyden dinosauruksen luiden kolinaa? Teoksessa Tolonen T. (toim.) Yhteiskunta ja sukupuoli. Nuorisotutkimusverkosto/Nuorisotutkimusseura julkaisuja 83. Tampere: Vastapaino, 8-17.

Tuschling, A., \& Engemann, C. (2006). From education to lifelong learning: The emerging regime of learning in the European Union. Educational Philosophy and Theory 38(4), 451-469.

Uotinen, J. (2005). Merkillinen kone: Informaatioteknologia, kokemus ja kertomus. Joensuun yliopiston humanistisia julkaisuja 40. Joensuu: Joensuun yliopisto.

Vaahtio, E.-L. (2003). Työmarkkinaikää ei lasketa kalenterista. Tutkimus rekrytoinnista, iästä ja ageismista. Työpoliittinen aikakauskirja 2, 42-56. http://www.mol.fi/mol/fi/99_pdf/fi/06_ tyoministerio/06_julkaisut/aikakausi/tak/ TAK_2003_2_5.pdf

Vuorio-Lehti, M. (2006). Valkolakin viesti. Ylioppilastutkintokeskustelu Suomessa toisen maailmansodan jälkeen. Turun yliopiston julkaisuja 253. Turku: Turun yliopisto.

Walkerdine, V. (1998). Counting girls out: Girls and mathematics. London: Falmer Press.

\section{VIITTEET}

\footnotetext{
1. Haastateltavien nimet on muutettu

2. Kristiina Brunila $(2009,103)$ on väitöskirjassaan "Parasta ennen: Tasa-arvotyön projektitapaistuminen" viitannut käsitteellä "parasta ennen" pakkoon tuottaa jatkuvasti "uusia" tuloksia tasa-arvotyössä. Tässä artikkelissa viittaan parasta ennen ikään oppimisessa ja koulutuksessa.
} 